\title{
Hurricane impacts on the foraging patterns of bottlenose dolphins Tursiops truncatus in Mississippi Sound
}

\author{
Courtney E. Smith ${ }^{1, *}$, Brendan J. Hurley ${ }^{2}$, Christina N. Toms ${ }^{1}$, Angela D. Mackey ${ }^{1}$, \\ Moby Solangi ${ }^{3}$, Stan A. Kuczaj II $^{1}$
}

\author{
${ }^{1}$ Department of Psychology, University of Southern Mississippi, Hattiesburg, Mississippi 39406, USA \\ ${ }^{2}$ Department of Geography and GeoInformation Science, George Mason University, Fairfax, Virginia 22030, USA \\ ${ }^{3}$ Institute for Marine Mammal Studies, Gulfport, Mississippi 39502, USA
}

\begin{abstract}
Acute catastrophic events, such as hurricanes, have various degrees of impact on marine mammal populations. Although changes in environmental conditions of affected areas have been examined for many storms, little attention has been given to the ecological effects on top-level predators. A longitudinal study on bottlenose dolphin Tursiops truncatus behavior and distribution in Mississippi Sound has been ongoing since 2003, allowing the unique opportunity to examine the impacts of the passage of Hurricane Katrina on this coastal dolphin population. Previous research showed an increase in reproductive rates within this population following Hurricane Katrina, most likely due to an increase in prey density following the sharp decline in commercial fishing efforts. In this paper, the frequency and distribution of dolphin foraging encounters in Mississippi Sound were examined from 2003 to 2009, revealing both short- and potentially long-term effects on dolphin foraging patterns following the hurricane. A pulse in dolphin foraging encounters was observed, which increased by $15 \%$ in the 2 yr following the hurricane before returning to pre-Katrina levels. Statistically significant hot spots were identified through the use of the Getis-Ord $\mathrm{Gi}^{*}$ hot spot analysis and revealed spatial shifts in foraging habitat consistent with prey selectivity. The results of this study support previous findings that coastal bottlenose dolphins in the southeastern United States are selective feeders, preferring to forage in deeper water known for soniferous prey species. Furthermore, this study presents important baseline information for future studies investigating other acute catastrophic events in Mississippi Sound, such as cumulative impacts following the Deepwater Horizon oil spill.
\end{abstract}

KEY WORDS: Tursiops truncatus · Hurricane impacts · Getis-Ord Gi* · Foraging ecology · Mississippi Sound

Resale or republication not permitted without written consent of the publisher

\section{INTRODUCTION}

Hurricanes cause catastrophic changes to coastal marine ecosystems. Strong winds, large amounts of precipitation, and storm surge can greatly alter the physical structure of existing shorelines and barrier islands. Water chemistry can be dramatically altered for weeks following a storm due to changes in salinity, resuspension of large volumes of sediments and nutrients (Allison et al. 2005, Dreyer et al. 2005), and large increases in contaminant input (e.g. chemicals, sewage, fuels, and pesticides; Burkholder et al. 2004, Bassos-Hull \& Wells 2007). Subsequent increases in total nitrogen and phosphorus from contaminant loadings can lead to hypoxic environments (Burkholder et al. 2004, Bassos-Hull \& Wells 2007), causing short-term changes in prey distribution and availability (Stevens et al. 2006, Tomasko et al. 2006) and, 
in some cases, massive fish kills (Burkholder et al. 2004).

The effects of such natural disasters on wildlife populations are poorly understood and difficult to assess due to the limited predictability of storm occurrence, course, strength, and location of impact. This is particularly true for wide-ranging and longlived marine megafauna, such as marine mammals, which require multi-year studies to be in place prior to a disaster to adequately measure effects. Some immediate and direct effects of hurricanes on marine mammals have been documented, such as the temporary displacement or stranding of individuals (e.g. dugongs Dugong dugon: Marsh 1989; pygmy killer whales Feresa attenuata: Mignucci-Giannoni et al. 1999; bottlenose dolphins Tursiops truncatus: Rosel \& Watts 2008). Other effects may manifest on a longer time scale, particularly if food resources are depleted or unavailable. For example, tropical storms have destroyed seagrass beds (a primary food source for dugongs), which has subsequently been related to increases in dugong mortality (Heinsohn \& Spain 1974, Preen \& Marsh 1995). Likewise, habitat destruction in important foraging areas following severe tropical systems is thought to have indirectly increased mortality in Florida manatees Trichechus manatus latirostris (Langtimm et al. 2006). Studies assessing hurricane impacts on the foraging ecology of cetaceans are greatly lacking, and to the best of our knowledge none has been reported in the literature. Given that the distribution patterns and behavior of cetacean species appear to be dependent on foraging habitat (see Würsig 1986, Hastie et al. 2004, Ashe et al. 2010), it is important to identify these areas and the mechanisms that shape them to better understand potential impacts of hurricanes and other catastrophic events.

Hurricane Katrina devastated the coastlines of Louisiana, Mississippi and Alabama on 29 August 2005. With storm surge as high as 24 to 28 feet ( 7.3 to $8.3 \mathrm{~m}$ ) along the Mississippi coast, Katrina is ranked the third most deadly and intense (ranked by pressure) tropical cyclone to make landfall in the period 1851-2006 (Blake et al. 2007). A project aimed at understanding the behavior and distribution of bottlenose dolphins in Mississippi Sound has been underway since 2003, showing regular use of this habitat by individuals on both a seasonal and yearround basis (Mackey 2010), thus providing a unique opportunity to examine the impacts of a major hurricane on this coastal dolphin population. In a previous study, Miller et al. (2010a) investigated the effects of Hurricane Katrina on bottlenose dolphin reproduc- tion, reporting an increase in the rate of calf sightings (calves $\mathrm{km}^{-1}$ effort), and in the percentage of calves to non-calves per group. The authors attributed this increase in reproduction, in part, to a potential increase in prey abundance in the area following a widespread reduction in the purchase of commercial and residential fishing licenses, as well as large decreases in annual fisheries landings in GulfportBiloxi, Mississippi, in the year of the storm (7.4 million $\mathrm{kg}$ of fish reported in 2004 compared to 3.9 and 4.4 million $\mathrm{kg}$ in 2005 and 2006, respectively; National Marine Fisheries Service 2007).

To complement the work of Miller et al. (2010a) and further explore the potential effects of hurricanes on bottlenose dolphin populations, the goals of this study were to (1) examine indirect evidence for an increase in fish abundance (i.e. dolphin prey) following Hurricane Katrina by means of foraging behaviors and comparison to reported fisheries landings, and (2) identify habitat usage related to dolphin foraging activities (dolphin foraging hot spots) before and after Hurricane Katrina.

\section{MATERIALS AND METHODS}

\section{Study area}

Mississippi Sound, hereafter referred to as 'the Sound,' is a relatively shallow ( $\sim 3.0 \mathrm{~m}$ average water depth) coastal system that extends from Louisiana to Alabama, and is separated from the Gulf of Mexico by a series of 5 barrier islands located 15 to $20 \mathrm{~km}$ from the main coastline: Cat, Ship, Horn, Petit Bois and Dauphin Islands, which comprise the National Park Service's Gulf Islands National Seashore (Fig. 1). These barrier islands exhibit various levels of erosion, as they are prone to absorbing storm surge and flooding from tropical systems. Ship Island was split into 2 islands (East Ship and West Ship) following Hurricane Camille in 1969; however, because the newly created pass (Camille Cut) was too shallow to survey, Ship Island was treated as a single barrier island for the present study. Aside from several patches of oyster beds, the topography of the Sound mainly consists of soft bottom substrates ranging from fine grain sand to mud (Moncreiff 2007). These latter areas are ideal for supporting dense seagrass habitats, which are important foraging areas for numerous fish, seabird, and marine mammal species. Multiple mainland watershed sources from the north, combined with tidal exchange with the Gulf of Mexico contribute to a wide range of salinities across 


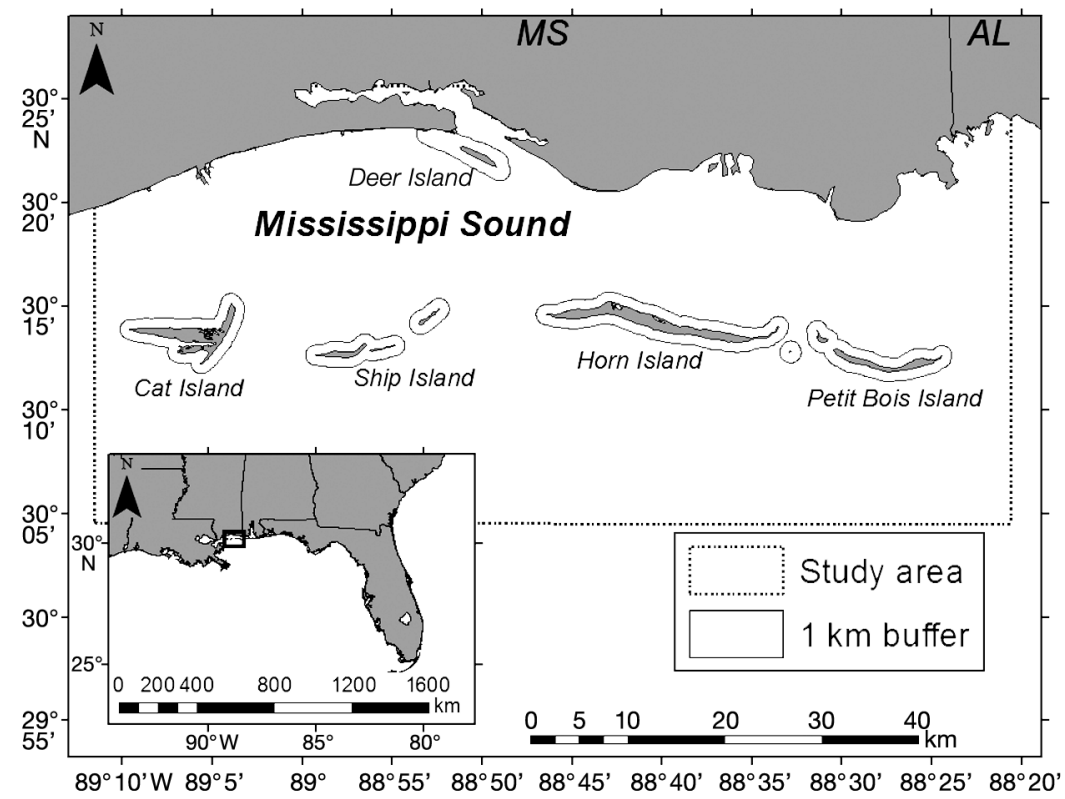

Fig. 1. Map of study area. Surveys were conducted on a random rotation around Cat, Ship, Horn and Deer Islands over a 6 yr study period. The $1 \mathrm{~km}$ buffer surrounding the islands represents the area targeted during surveys

the Sound, which during the course of the study ranged from 6 to $41 \mathrm{ppt}$ (mean $=23 \mathrm{ppt}$ ). Sea surface temperatures during the current study ranged from a low of $5^{\circ} \mathrm{C}$ in the winter to a high of $33^{\circ} \mathrm{C}$ in the summer, averaging an annual mean of $23^{\circ} \mathrm{C}$. The average depth during each encounter in the current study ranged from 0.60 to $18 \mathrm{~m}$, with a mean depth of $4.85 \mathrm{~m}$.

\section{Data collection}

Data were collected during directed, non-transect surveys targeting the Mississippi coast barrier islands from September 2003 through September 2009. Surveys were alternated randomly between select islands, but under the condition that each island was surveyed at least once each month and an equal number of times each season. Early surveys conducted from September 2003 to June 2005 rotated between Cat $\left(30^{\circ} 13^{\prime} \mathrm{N}, 89^{\circ} 06^{\prime} \mathrm{W}\right)$ and Ship Islands $\left(30^{\circ} 12^{\prime} \mathrm{N}\right.$, $\left.88^{\circ} 56^{\prime} \mathrm{W}\right)$. Horn Island $\left(30^{\circ} 14^{\prime} \mathrm{N}, 88^{\circ} 42^{\prime} \mathrm{W}\right)$ was incorporated into the study area in July 2006, but was later replaced by Deer Island $\left(30^{\circ} 22^{\prime} \mathrm{N}, 88^{\circ} 50^{\prime} \mathrm{W}\right)$ in June 2009. ${ }^{1}$ Surveys were conducted at least 4 times a month, weather permitting, from one of the following platforms: a 7 to $10 \mathrm{~m}$ vessel powered by a 225 Ram injection Evinrude outboard motor, or a center console

${ }^{1}$ Deer Island was once an extension of the mainland and is not considered a barrier island
Nautica rigid inflatable catamaran with twin 150-horsepower Evinrude engines. Surveys originated from either Gulfport Harbor or the Back Bay of Biloxi, beginning at $\sim 08: 30 \mathrm{~h}$ and continued until the scheduled island had been surveyed completely or until weather conditions deteriorated (e.g. Beaufort sea state $>3$ ). During each survey, a minimum of 3 observers continuously scanned for dolphins while the research vessel traveled at a speed of 16 to $20 \mathrm{~km} \mathrm{~h}^{-1}$. The vessel circumnavigated each respective island at a distance of 1 to $1.5 \mathrm{~km}$ from shore. When a group of dolphins was spotted, the research vessel maneuvered toward the group and data collection began. A group of dolphins was defined as individuals within $100 \mathrm{~m}$ of each other and engaged in similar activities (Irvine et al. 1981). At the beginning of a dolphin encounter, the time and location were determined using a Garmin GPSMap 76 global positioning device, and environmental conditions (e.g. weather, Beaufort sea state, depth, salinity, glare, and water and air temperature) were recorded. Behavioral data were collected throughout the duration of the encounter following an ethogram derived from Shane (1990; also see Miller et al. 2010b; Table 1).

From September 2003 to June 2006, behavioral data were collected using all-occurrence sampling (Altmann 1974) for behavioral events, while behavioral states were rank-ordered based on amount of occurrence during the observation period (determined once the encounter ended). From July 2006 through September 2009, behavioral data were collected using a combination of instantaneous sampling for behavioral states and all-occurrence sampling for behavioral events (Altmann 1974). The behavioral state of the group (based on the activity of the majority of group members) was recorded at 1 min intervals. If the majority of the group was underwater at the interval, the behavioral state was recorded as the same as the state prior to submerging if it was the same upon the next surfacing (Mann 1999). If the state differed upon the next surfacing, the behavioral state was recorded as 'Not Found'. Interobserver reliability was determined using previously recorded video footage of bottlenose dolphin behaviors observed in Mississippi Sound, which involved coding behavioral states, events, and group size estimates; interobserver reliability was held constant at $r>0.80$ throughout the study period. 
Table 1. Tursiops truncatus. Operational definitions of behavioral states and events used to determine foraging encounters. See Miller et al. (2010b) for full ethogram used in surveys

\begin{tabular}{|c|c|}
\hline Foraging behavior & Operational definition \\
\hline \multicolumn{2}{|l|}{ Behavioral states } \\
\hline Feed & $\begin{array}{l}\text { Group of dolphins is engaged in foraging behaviors such as repeated fluke-in/out dives in one } \\
\text { location, feeding circles, lunge feeds, fish kicks, fish tosses, etc. }\end{array}$ \\
\hline Probable feed & $\begin{array}{l}\text { Indications of feeding such as group of dolphins following shrimp boat or birds diving in the immedi- } \\
\text { ate vicinity of the group. }\end{array}$ \\
\hline \multicolumn{2}{|l|}{ Behavioral events } \\
\hline Chase fish & $\begin{array}{l}\text { A rapid increase in speed; observed in dolphins swimming in normal orientation or side-swim; fish } \\
\text { must be observed to record this event. }\end{array}$ \\
\hline Fish in mouth & Dolphin surfaces with fish visible between jaws. \\
\hline Fish kick & Dolphin uses fluke or peduncle to knock a fish into the air. \\
\hline Fish toss & Fish is thrown into the air by a dolphin using its melon, rostrum, or teeth. \\
\hline Lunge feed & $\begin{array}{l}\text { An accelerated forward motion at the surface that creates a wake moving the distance of approxi- } \\
\text { mately one body length. }\end{array}$ \\
\hline
\end{tabular}

A given group was followed until (1) a minimum of 15 min of behavioral data was collected, (2) the dolphins disappeared from view and were not located again, (3) weather conditions deteriorated, or (4) the dolphins showed signs of disturbance. Upon ending an encounter, the time, location, group composition (presence/absence of calves), and group size were recorded. Group size included the minimum, maximum, and best estimate of the number of dolphins present with the consensus of the observers.

\section{Data analysis}

Ethogram data were reviewed for recordings of dolphin foraging behavior over the study period. To control for biases against longer encounters (i.e. greater opportunity to observe foraging) we only reviewed ethogram data from the first $15 \mathrm{~min}$ of each encounter. Due to the methodological changes in behavioral data collection, only presence/absence information were retained and used for analyses. An encounter was considered a foraging encounter and included in the analysis if 'Feed' or 'Probable Feed' were recorded as a behavioral state or if any other foraging events were recorded during the encounter (Table 1). Of the total 266 survey days with 354 foraging encounters, 26 days (with 19 foraging encounters) were eliminated from the analyses due to incomplete data for survey effort calculations, the lack of encounters of any kind, or because of extremely short surveys (outliers). Analyses included the remaining 240 total survey days with 1049 encounters, 335 of which were considered foraging encounters (see Appendix 2 for survey effort). To have comparable time periods, our 72 mo study period was divided into 3 hurricane phases of 24 mo each: Pre-Katrina
(Pre-Kat; September 2003-August 2005), Post-Katrina 1 (Post-Kat 1; October 2005-September 2007), and Post-Katrina 2 (Post-Kat 2; October 2007-September 2009). No surveys were conducted in September 2005 due to post-hurricane debris and coastal damage. In order to account for natural seasonal variation in foraging behavior, data were further analyzed across the summer (May-October) and winter (November-April) months as determined by mean sea surface temperature.

\section{Frequency of foraging encounters}

Survey effort was accounted for by creating a foraging index for each survey day based on the proportion of foraging encounters to total encounters recorded relative to distance surveyed each day:

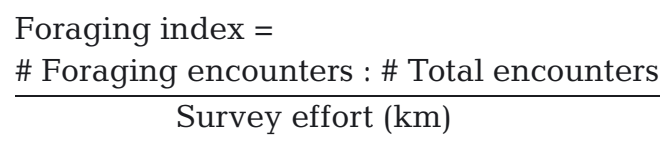

SPSS was used to conduct a Kruskal-Wallis test on ranked data to examine significant differences in the frequency of foraging encounters (using the foraging index) between hurricane phases and several control survey variables: survey effort distance, average group size, and number of overall encounters per kilometers surveyed. Mann-Whitney $U$-tests, with a Bonferroni correction ( $\alpha=0.02 ; 2$-tailed), were used for follow-up comparisons. Effect sizes $(r)$ were calculated for significant comparisons. A Mann-Whitney $U$-test was also used to examine foraging behavior between seasons ( $\alpha=0.05$; 2 -tailed).

The reported decline in annual commercial fisheries landings in Gulfport-Biloxi in the year of hurricane Katrina (National Marine Fisheries Service 
2007) would be expected to positively influence prey abundance, suggesting an inverse relationship between reported fisheries landing and the frequency of foraging encounters. To test this, monthly foraging indices were also calculated and compared with monthly fisheries landings data (only available statewide, instead of specific to Gulfport-Biloxi; National Marine Fisheries Service 2012a) for the same period using a Pearson's correlation (1-tailed, $\alpha=0.05$ ).

\section{Getis-Ord Gi* hot spot analysis}

ArcGIS version 10.0 provides a statistically powerful hot spot analysis using the Getis-Ord Gi* statistic (Getis \& Ord 1992). The Gi* analysis calculates a Zscore for each feature in a set of weighted features (in the case of this analysis the weighted features were effort-corrected grid cells of $1 \mathrm{~km}^{2}$ resolution). This $Z$-score (the $\mathrm{Gi}^{*}$ statistic) indicates whether features with high or low values tend to cluster in a given area. Specifically, each feature is compared with neighboring features, and then by local summation compared to a global sum (all features in the study area); when this local sum is different from the expected local sum, and that difference is too large to be the result of random chance, a statistically significant $Z$-score is the result. If a feature's value is high and the values for all neighboring features are also high, it is part of a hot spot. Hot spots are defined as areas with statistically significant high $Z$-scores $(\mathrm{p}<$ 0.05 ), and conversely cold spots are areas of statistically significant low $Z$-scores ( $p<0.05$, ESRI ArcGIS Resource Center 2011a).

Effort-corrected survey data were parsed into multiple temporal splits to highlight any clustering patterns by season, year, and whether the data were temporally before or after Hurricane Katrina (see Appendix 1). Grid cells $\left(1 \mathrm{~km}^{2}\right)$ were chosen based on encounters coded as foraging encounters following the methods previously mentioned. Encounters were recorded with a start and end latitude and longitude, thus allowing for centroid calculations for each encounter. The average length value of foraging encounters during surveys was $1014 \mathrm{~m}$ (or $\sim 1 \mathrm{~km}$ ).

Foraging sightings per unit effort (sightings $\mathrm{km}^{-1}$ ) for each grid cell were then produced by dividing the number of foraging encounters in each grid cell by the length $(\mathrm{km})$ of trackline surveyed in that same grid cell. From these, the closest (by distance) $95 \%$ of sightings were retained. The farthest (by distance) $5 \%$ were dropped to minimize the impact of outlying areas that were rarely surveyed, preserving the integrity of the hot spot analyses given that the survey design was opportunistic. Incremental Spatial Autocorrelation (utilizing iteration of the Global Moran's I function) tools for all files were first seeded with the output of a preliminary Average Nearest Neighbor analysis (ESRI ArcGIS Resource Center 2011b), and then performed on all files in order to find distances at which, if present, autocorrelation is maximized (in this case, clustered foraging events). These distances were then included in custom Spatial Weights Matrices (again for each respective file). Spatial Weights Matrices allow for a tighter control over how the groupings of cells interact. For this analysis, a minimum of 8 neighbors for each cell were required (ESRI ArcGIS Resource Center 2011c), as well as a threshold distance (as determined with the Incremental Spatial Autocorrelation analysis) beyond which outer cells' influence decreased rapidly (inverse distance squared). If, however, 8 neighbors could not be found within the given threshold distance, the distance was temporarily extended in order to satisfy this rule. After these preparatory analyses were completed, the final Spatial Weights Matrix of each respective file was then used as the customized input parameter for the Getis-Ord $\mathrm{Gi}^{*}$ analysis.

Mitchell (2009) points out that the independence of tests is inherently violated during the Getis-Ord Gi* (e.g. each cell's local calculations rely on other local cells), thus producing Type I errors. The Bonferroni correction (Quinn \& Keough 2002) was employed in order to mitigate the chances of this happening. While the correction is somewhat conservative, the opportunistic nature of the data used in the analysis warranted conservative estimations. Finally, to be included in the results, a hot spot must have been surveyed in the Pre-Kat phase, as well as at least one Post-Kat phase to ensure that those particular cells that appeared as hot spots in one phase were surveyed again to allow for a fair comparison.

\section{RESULTS}

\section{Frequency of foraging encounters}

There was a significant difference in foraging between the 3 hurricane phases $(H=12.379, \mathrm{df}=2, \mathrm{p}=$ $0.002, \eta^{2}=0.052$ ) with a mean rank of $112.18,141.29$, and 106.42 for Pre-Kat, Post-Kat 1, and Post-Kat 2, respectively. The proportion of foraging encounters to total encounters for each of the Pre-Kat and PostKat 2 phases was $\sim 25 \%$, which is consistent with past 
evaluations of dolphin foraging behavior within the Sound (Mullin 1988). However, this proportion was $40 \%$ in the phase immediately following Hurricane Katrina (Post-Kat 1), representing a $\sim 15 \%$ increase in the proportion of foraging encounters (accounting for effort) compared to PreKat (Table 2; Pre-Kat vs. Post-Kat 1) and Post-Kat 2 (Table 2; Post-Kat 1 vs. Post-Kat 2). There was no significant difference between Pre-Kat and Post-Kat 2 (Table 2, Fig. 2). Additionally, there was no significant difference in foraging between seasons $(U=6760.50, Z=-0.753$, $\mathrm{p}=0.451$ ).

Considering our control survey variables, there were no significant differences in survey effort distance $(H=0.557, \mathrm{df}=2, \mathrm{p}=0.757)$ or average group size $(H=$ 4.482, df $=2, \mathrm{p}=0.106$ ) between each hurricane phase. However, the total number of encounters, accounting for effort, differed significantly across hurricane phases $\left(H=9.435, \mathrm{df}=2, \mathrm{p}=0.009, \eta^{2}=\right.$ 0.04). There were fewer total encounters in Post-Kat 2 than in Post-Kat 1 (Table 2), but no differences between Pre-Kat and Post-Kat 1, or Pre-Kat and PostKat 2 hurricane phases (Table 2). Finally, although the effect was small, a significant correlation was found between the fisheries landings data and the foraging indices $(r=-0.217, \mathrm{p}=0.035, \mathrm{n}=70$; e.g. Fig. 3).

\section{Getis-Ord Gi* hot spot analysis}

Cells were retained for analysis if they contained at least one foraging event. In all, 335 foraging events were identified within 233 cells: 65 in the Pre-Kat phase, 106 in Post-Kat 1, and 62 in Post-Kat 2 (Fig. 4). After applying the Bonferroni correction, however, only 3 significant hot spots remained (Fig. 5). Two hot spots occurred in the Pre-Kat phase (Bonferroni corrected $\mathrm{p}$-value $<0.001$ ), a single hot spot was identified in the Post-Kat 1 phase (Bonferroni corrected pvalue $<0.0005$ ), and no hot spots were found during the Post-Kat 2 phase (Bonferroni corrected p-value < 0.001). No seasonal hot spots were found within the seasonal split analysis. Though only 3 cells are identified as hot spots, each cell uses other cells within the foraging dataset to be calculated and so these hot spots are derived from information inherent within many cells. While the results only highlight 3 hot spot cells, the opportunistic survey design we used warranted a highly parsimonious approach to analysis.

\section{DISCUSSION}

Dolphin foraging activity increased significantly following the passage of Hurricane Katrina and remained elevated throughout the Post-Kat 1 phase (Fig. 6). These results suggest that there may have been an increase in feeding opportunity, prey abundance, and/or a need for increased food consumption

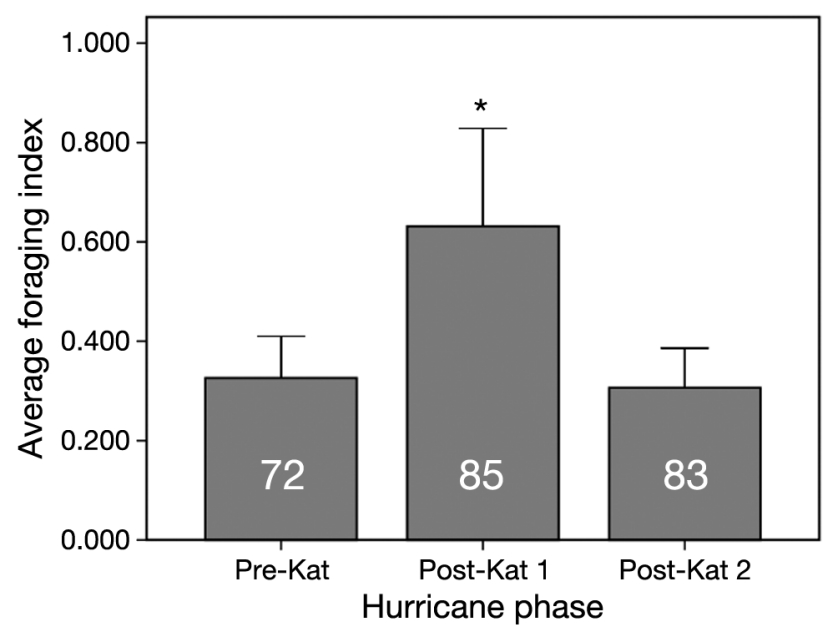

Fig. 2. Tursiops truncatus. Average frequency $( \pm \mathrm{SE})$ of foraging encounters across hurricane phases, using the foraging index (proportion of foraging to non-foraging encounters $\mathrm{km}^{-1}$ survey effort). Asterisk indicates significant differences $\left({ }^{*} \mathrm{p}<0.01\right)$ as determined by Mann-Whitney $U$ post hoc tests (adjusted $\alpha=0.02$ ). Numbers inside the bars show the total number of surveys conducted during that phase. Pre-Kat: September 2003-August 2005; Post-Kat 1: October 2005-September 2007; Post-Kat 2: October 2007September 2009 ( $\mathrm{N}=240$ surveys $)$ 


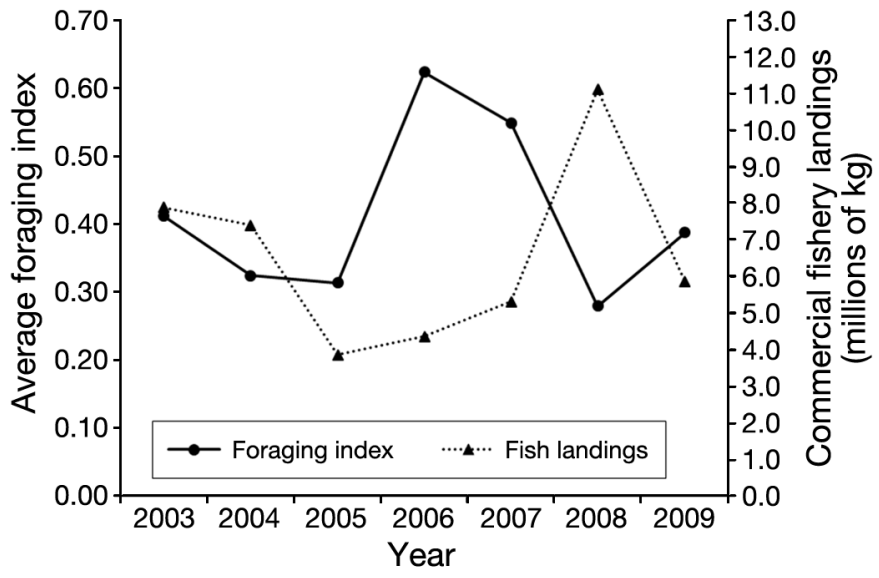

Fig. 3. Tursiops truncatus. Relationship between annual commercial fisheries landings for Gulfport-Biloxi (National Marine Fisheries Service 2012b) ( $\mathbf{\Delta}$ ) and the average foraging index $(\bullet)$ for each year of the study period. Foraging index is the proportion of foraging to non-foraging encounters $\mathrm{km}^{-1}$ survey effort

following the hurricane; however, it is difficult to determine the mechanisms that resulted in increased foraging. Our results offer indirect evidence of the intermediate disturbance theory; hurricanes and other acute catastrophic events may create levels of disturbance that can maximize species diversity (Connell 1978). It is likely, however, that there are multiple factors interacting and influencing the observed patterns.

A number of studies have reported that the presence of vessels leads to decreases in cetacean foraging behavior (Aguilar Soto et al. 2006, Miller et al. 2008, Lusseau et al. 2009). The reduction in vessel traffic following the storm may have given bottlenose dolphins in the Sound more time and/or space to forage. Moreover, commercial and recreational fishing within the Sound targets many of the same fish species utilized as prey by bottlenose dolphins (Leatherwood 1975, Benson 1982, Barros \& Odell 1990, Barros \& Wells 1998, Berens McCabe et al. 2010): striped mullet Mugil cephalus, pinfish Lagodon rhomboids, Gulf menhaden Brevoortia patronus, jack Caranx hippos, and spot Leiostomus xanthurus. A decrease in fisheries targeting these species for a period after

Fig. 4. Tursiops truncatus. Survey effort and resulting foraging hot spots in the Mississippi Sound region, by hurricane phase: (a) Pre-Kat, (b) Post-Kat 1, and (c) Post-Kat 2. Significant hot spots following Bonferroni correction are bullseyed. Note: Petit Bois Island was opportunistically surveyed during 2 Horn Island surveys in the Pre-Kat phase, but was not surveyed the remainder of the study (see Appendix 2 for effort)
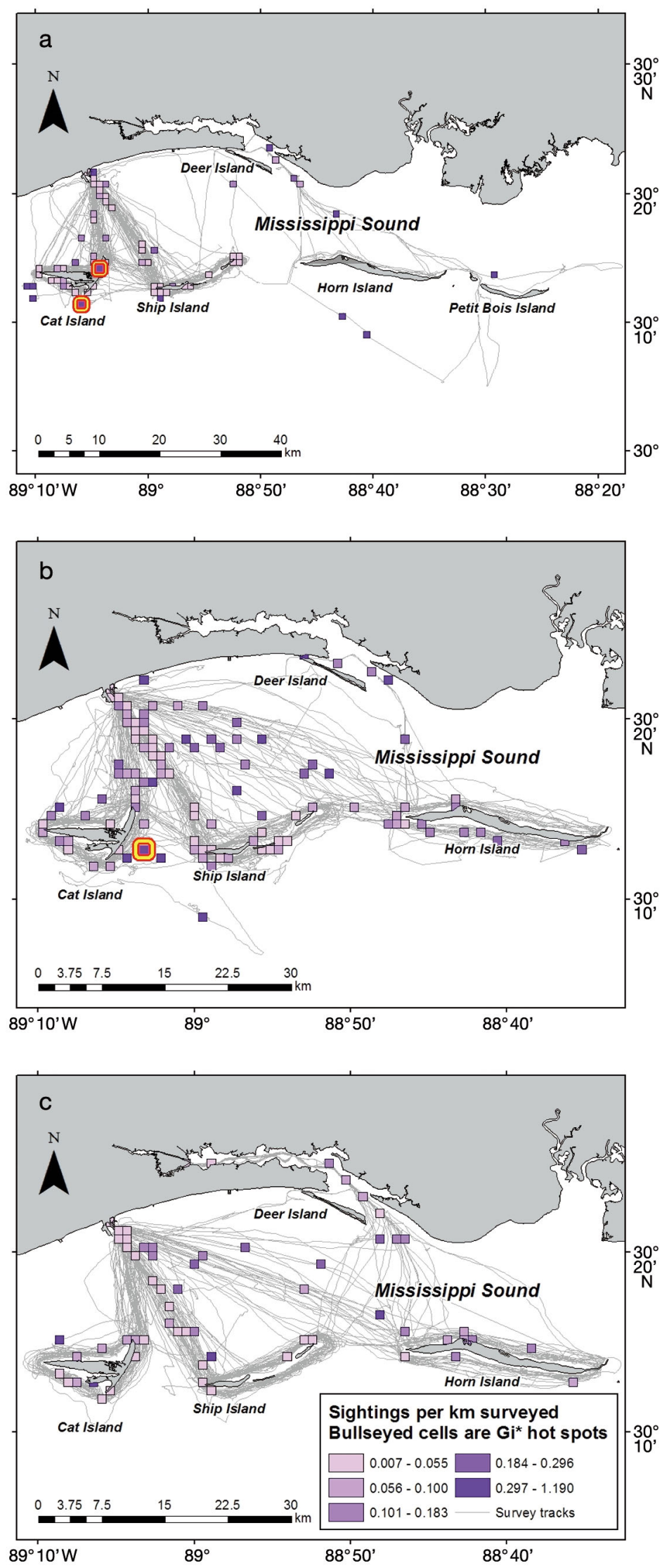


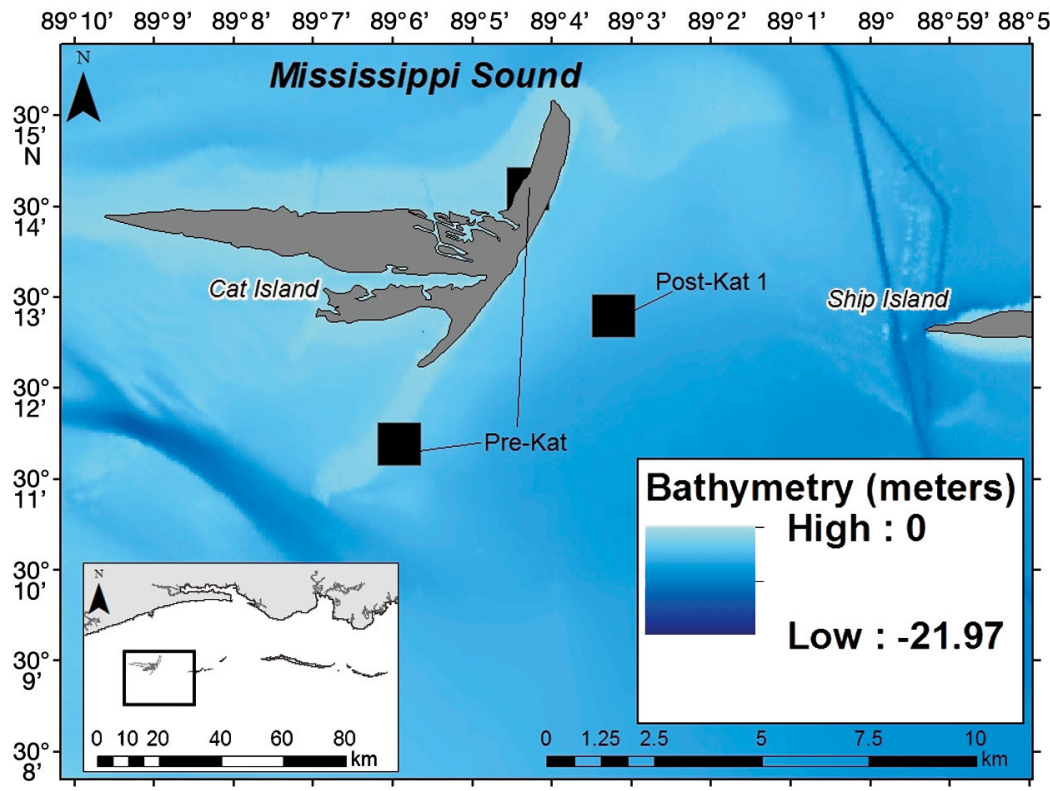

Fig. 5. Tursiops truncatus. Foraging hot spots as identified by the Getis-Ord Gi* statistic (bathymetry from Love et al. 2012). Two hot spots were identified during the Pre-Kat phase in shallow waters (westerly black squares) while the Post-Kat 1 hot spot was in deeper waters (single easterly black square as indicated)

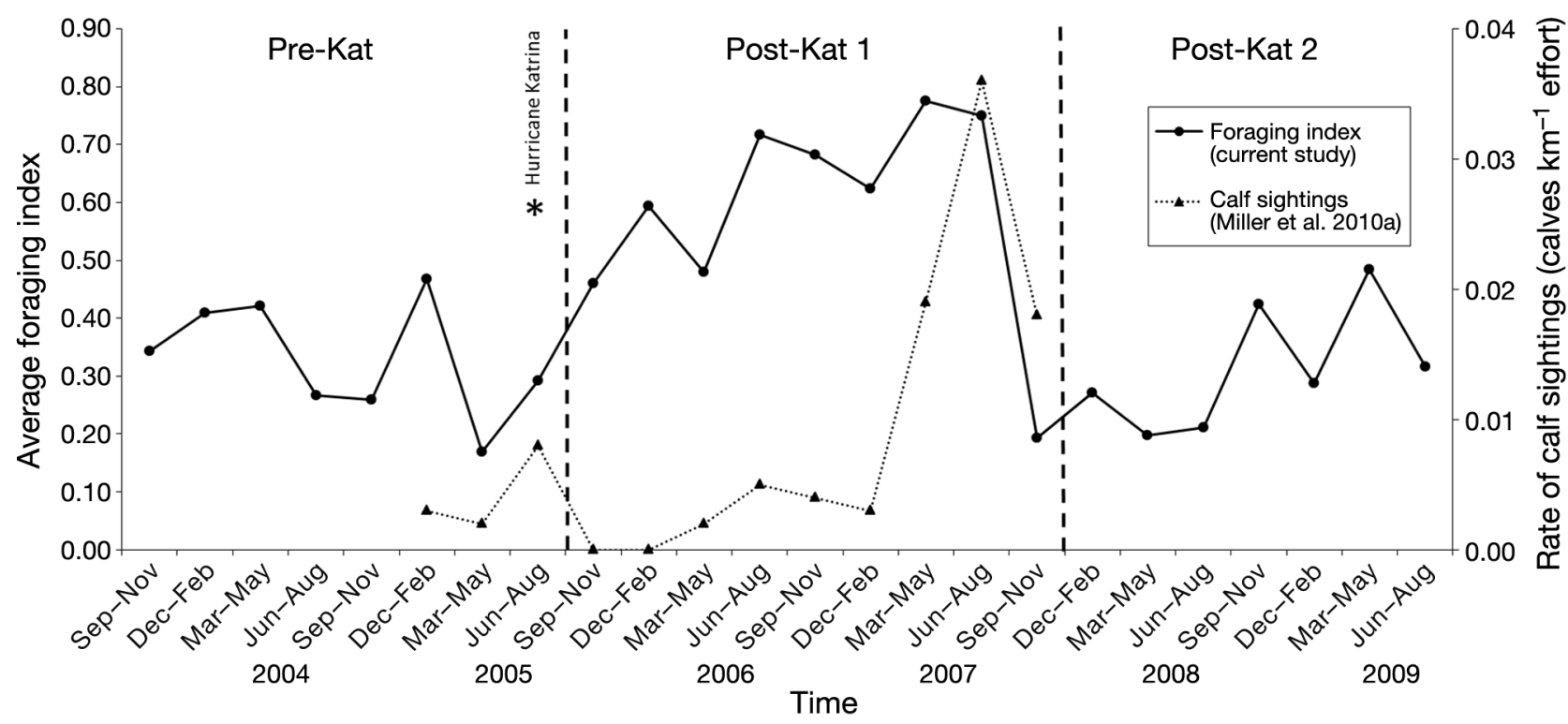

Fig. 6. Tursiops truncatus. Changes in average foraging index (•) throughout the study period. Foraging index is the proportion of foraging to non-foraging encounters $\mathrm{km}^{-1}$ survey effort. Data from Miller et al. (2010a) (ム) shows increase in dolphin reproductive activity during the increased foraging activity observed in the current study. Dashed vertical lines indicate hurricane phases: Pre-Kat: September 2003-August 2005; Post-Kat 1: October 2005-September 2007; Post-Kat 2: October 2007-September 2009. Note: foraging index data were averaged over 3 mo periods to correspond with the seasons analyzed in Miller et al. (2010a)

the storm likely resulted in increases in abundance of prey. This is supported by the significant negative correlation between foraging indices and the fisheries landings data over the course of the study (see Fig. 3). Furthermore, there was a documented decrease in both the purchase of statewide commercial and residential fishing licenses and in annual fisheries landings specific to Gulfport and Biloxi (National Marine Fisheries Service 2007, Miller et al. 2010a), suggesting a potentially prominent influence on prey availability and/or feeding opportunity in the study area following the hurricane. 
Similar effects were seen in Boca Ciega Bay, Florida, where sightings of bottlenose dolphins and calves significantly increased following the 1995 Florida net ban (Eide 1998). Likewise, the observed increase in foraging activity (and decrease in fisheries effort) corresponds to a reported overall increase in dolphin fecundity within the Sound (Miller et al. 2010a; our Fig. 6) following the hurricane, indicating there may have also been an increased need for food consumption. Females in the late stages of pregnancy and lactating females require much higher energy levels for milk production than nonreproductively active adults (Reddy et al. 1991) and therefore consume higher quantities of food during this time (Kastelein et al. 2002). It is unknown whether calf survivorship and/or overall reproductive success of females in the Sound also increased but evidence suggests that there was enough food to at least support a temporary increase in feeding needs. While an increase in observed foraging activities is not always indicative of an increase in prey consumption, there is enough evidence to suggest that this was the case following the hurricane (PostKat 1 phase).

In addition to the observed changes in the frequency of foraging encounters following Hurricane Katrina, each of the significant foraging hot spots were concentrated near Cat Island suggesting this area might be a preferred foraging habitat for dolphins. Cetacean distribution patterns are at least partially dependent on habitat features (Gowans \& Whitehead 1995, Baumgartner 1997, Davis et al. 1998, Redfern et al. 2006), and these features seem to be clear mechanisms in shaping preferred foraging habitat. For example, bottlenose dolphins near San Diego, California forage in nearshore reefs and kelp beds in a manner that reflects known prey distribution (Hanson \& Defran 1993). Likewise, bottlenose dolphins within the Moray Firth, Scotland have displayed seasonal variation for preferred foraging habitat, feeding over deep water and steep seabeds in summer months and moving to more shallow foraging areas during the winter (Hastie et al. 2004). For dolphins in the southeastern United States, most of the literature reports foraging activity that is directly associated with seagrass habitat (see Shane 1990, Waples 1995, Scott et al. 1996, Barros \& Wells 1998).

The northern shores of the Mississippi barrier islands were once prevalent with seagrass, with Cat Island having the greatest seagrass coverage and potential seagrass habitat of all the barrier islands within the Sound (Moncreiff 2007). However, seagrasses within the Sound have declined nearly $50 \%$ over the last 5 decades due to declining water quality and an increase in turbidity, rather than storm impacts (Moncreiff et al. 1998). In fact, recent evidence suggests that Hurricane Katrina had variable effects on seagrass beds in this region (Anton et al. 2009, Carter et al. 2011). For example, from 2003 through 2007, Cat Island seagrass habitat more than tripled in size, growing from 22 ha to 71 ha (Carter et al. 2011). This growth seems to correspond with the shifts in foraging hot spots we observed at Cat Island; as seagrass extent increased, dolphins shifted their preferred foraging habitats to deeper waters (see Fig. 5). While these results contradict what historic literature reports with respect to preferred seagrass foraging habitat, more recent studies support this suggestion. For example, a fine-scale analysis of foraging habitat near Clearwater, Florida showed coastal bottlenose dolphins not only preferred foraging in natural and dredged channels rather than seagrass habitats, but that these areas had larger and more abundant amounts of pinfish Lagodon rhomboids, a preferred prey item (Allen et al. 2001). A similar study also incorporating stomach content data showed that dolphins in Sarasota Bay, Florida also target soniferous prey species that prefer deep water areas as opposed to seagrass habitat (Berens McCabe et al. 2010). Carbon isotope values taken from stranded dolphins in Sarasota Bay following the 1995 Florida net ban had shifted in a manner that was consistent with a decreased use of seagrass habitat; that is, when not in competition with commercial fisheries, coastal bottlenose dolphins exploited prey that were not as dependent on seagrass derived carbon (Rossman et al. 2011).

Similar influences may have been at play in the current study. The increase in foraging behavior following the hurricane also corresponds with the slight shift in foraging hot spots from known seagrass habitat during Pre-Kat ( 0.30 to $1.0 \mathrm{~m}$ in depth) to a deeper area $(\sim 5.0 \mathrm{~m}$ in depth) during Post-Kat 1 (Fig. 5). Seagrass habitats can significantly alter the transmission of bioacoustic signals and can provide an acoustic refuge for many smaller and juvenile soniferous prey species (Wilson et al. 2013). Given that bottlenose dolphins use both active and passive acoustic means of locating prey, it may be more energetically costly to target the smaller species inhabiting these areas than the larger prey found in alternative habitats (Gannon et al. 2005, Nowacek 2005). These combined factors may support the growing notion that bottlenose dolphins are selective feeders, rather than opportunistic, preferring a foraging habitat known for larger, soniferous fish species when 
prey are likely more abundant (Barros \& Wells 1998, Gannon et al. 2005, Berens McCabe et al. 2010, Rossman et al. 2011).

The lack of foraging hot spots and overall decrease in both the total encounters and number of foraging encounters during Post-Kat 2 could be related to several factors. For example, seagrass habitat is indirectly linked to the health of coastal dolphin populations and the degradation of these areas likely elicits shifts in bottlenose dolphin foraging strategies. Recent dredging activities in the main shipping channel between Cat and Ship Islands is thought to have caused substantial erosion along the southern spit and eastern shoreline of Cat Island-which was weakened significantly following Hurricane Katrinaleading to a clockwise rotation of the island's perimeter (the sediments were transported by currents and deposited along the northern and western shorelines of the island; Fritz et al. 2007, Morton 2008) and a potential loss in seagrass habitat. This, combined with increased competition with commercial fisheries - annual landings for Gulfport-Biloxi more than doubled from 2007 to 2008 (National Marine Fisheries Service 2012b) - could explain the overall decrease in foraging encounters and complete lack of foraging hot spots during Post-Kat 2. Furthermore, the later end of the Post-Kat 2 phase is only a few months prior to the start of a widespread and ongoing (as of June 2013) unusual mortality event (UME) for Northern Gulf of Mexico cetaceans, which began in February of 2010 (NOAA Fisheries 2013). Between 1 February and 29 April 2010, 114 cetaceans stranded, a vast majority of which were bottlenose dolphins. Since these strandings took place prior to the response phase for the Deepwater Horizon oil spill, there is evidence suggesting many stressors may have already been acting on Northern Gulf of Mexico dolphin populations prior to the spill. For example, physiological stress from an unusually cold winter in 2010 combined with bacterial infection and depleted food resources are all thought to be responsible for the weakened body condition and poor overall health of stranded bottlenose dolphins during the said UME (Carmichael et al. 2012). The observed decrease in foraging (compared to Post-Kat 1) and lack of hot spots found in the Post-Kat 2 phase may be related and have carried over into the 2010-2012 cetacean UME. Furthermore, one year after the PostKat 2 phase (during summer and fall 2010), there were reports of genetic and physiological damage in nearshore fishes and declines in planktivorous fishes, suggesting a reduction in the dolphin prey base following this study (Whitehead et al. 2011, Patterson unpul. data as cited by Carmichael et al. 2012). As such, the present study provides an important baseline to examine how foraging patterns and behavior may have been modified with the UME and Deepwater Horizon oil spill.

Evidence was provided earlier that dolphins may be selective feeders, but little is known about how this may vary between different geographical or behavioral stocks that utilize the study area and subsequently how these interactions might relate to this hot spot analysis. The study area includes 2 of the 6 bay, sound, and estuary management stocks in the Sound and likely overlap with the northern coastal stocks. ${ }^{2}$ Inshore and coastal animals may be expected to target different kinds of prey in the same area. For example, Gannon \& Waples (2004) found marked differences in the diets of bottlenose dolphins that stranded in estuarine (croaker Micropogonias undulatus dominated diets) versus oceanic waters (weakfish Cynosicon regalis and squid Loligo sp. dominated diets) in North Carolina. Likewise, marked differences in carbon, nitrogen and sulfur isotopic signatures were found between animals stranded in bay, nearshore and offshore waters surrounding Sarasota Bay, Florida (Barros et al. 2010), suggesting differences in targeted trophic levels of prey and in the degree of seagrass dominated habitats utilized between inshore and coastal communities. Similar to other areas in the Gulf (Florida: Irvine et al. 1981, Wells et al. 1987, Barros \& Wells 1998, Balmer et al. 2008; Texas: Fertl 1994, Maze \& Würsig 1999), a portion of the dolphin population uses the study area on a regular basis, both year-round and seasonally (data from 2004-2007; Mackey 2010). However, it has been estimated that a majority $(73.5 \%)$ of individuals identified within the study area are transients (Mackey 2010), suggesting this location may be more of a transit area rather than a residential habitat for a closed or semi-closed dolphin population (e.g. Sarasota Bay, Florida: Irvine et al. 1981, Wells et al. 1987). As such, it is possible the Sound may be used as a foraging stopover for migratory and/or seasonal animals, particularly for pregnant or lactating females. More research is needed to examine dynamics between seasonal, resident and transient groups to determine if similar patterns emerged between inshore and coastal communities in the Sound compared to other areas. Stable isotope analyses are becoming more commonly used to dif-

\footnotetext{
${ }^{2}$ Bottlenose dolphin stock subunits are based largely on geographic features rather than empirical studies (Blaylock \& Hoggard 1994, Wade \& Angliss 1997)
} 
ferentiate foraging preferences (Walker et al. 1999, Worthy et al. 2011) as well as stock structure (Born et al. 2003, Witteveen et al. 2009) and could be utilized to greatly improve understanding of these dynamics in this area and how they relate to foraging hot spots.

Hurricane Katrina occurred at a time of year when dolphin abundance in the Sound is at its peak and when many coastal animals are expected to be closer inshore (Hubard et al. 2004, Miller et al. 2012). Combined with the subsequent decline in fisheries and vessel activities, there may have been a large disruption in the local group structure and social patterns during that time (e.g. Ansmann et al. 2012). Regardless of any potential short-term impacts on local group dynamics immediately following the hurricane, long-term impacts may be less adverse. For example, dolphin populations utilizing Charlotte Harbor, Florida demonstrated surprising resilience with few longterm changes in population dynamics 2 years following a major hurricane (Bassos-Hull \& Wells 2007). Additionally, if dolphins from neighboring areas immigrated into the study area following the hurricane (e.g. Elliser \& Herzing 2011), we may have observed an artificial increase in foraging activity. A population increase, however, would likely have been reflected in an increase in group size and/or number of encounters per survey-neither of which were observed in the current study. Moreover, there was no significant increase in the number of new dolphin identifications following the storm (Mackey 2010) and abundance and density estimates in 20072008 (Miller et al. 2012) were similar to those many years prior to the storm (Hubard et al. 2004).

We cannot eliminate the possibility of hot spots existing mid-Sound or near Deer or Horn Islands. Survey effort was not evenly distributed throughout the study area since the research focus was on the nearshore waters bordering the barrier islands. Additionally, the survey area was not of consistent size throughout the study given the rotation of Deer and Horn Islands toward the end of the study period. Although the lack of historic seagrass coverage midSound (Moncreiff 2007) makes hot spots in these areas unlikely, Horn Island once had comparable seagrass coverage to that of Cat Island (Moncreiff 2007, Peneva et al. 2008); it is possible that preferred foraging habitat shifted from Cat Island to Horn Island, since Horn Island was surveyed only 3 months during the Post-Kat 2 phase, explaining why we observed fewer overall encounters during PostKat 2 than during the Post-Kat 1 phase. To eliminate this possibility in future studies, dedicated markrecapture surveys should be conducted using tran- sects across the entire Sound-rather than just targeting the barrier islands-ensuring equal effort across the study area.

Bottlenose dolphin foraging habits are dynamic over time, often with changes in both the frequency and distribution of foraging activities likely driven by cumulative effects derived from natural and anthropogenic factors. The temporary cessation of commercial fishing activities as a result of hurricane related damage and debris led to an increase in prey abundance, as evidenced by the increase in foraging encounters. Additionally, the spatial shifts in preferred foraging areas during this time support the growing theory that bottlenose dolphins are selective feeders. The data and subsequent results presented here were derived from surveys that were not designed with the objectives of the current study in mind, and although the post-hoc nature of the study warranted relatively high conservative thresholds for hot spot identification, this method should be considered by future researchers when identifying areas of concentrated usage by marine mammals. Furthermore, few published data regarding past environmental variables relative to the Mississippi Sound ecology were available during the course of the study. Future surveys that incorporate systematic prey sampling, bathymetry, hypoxia conditions and seagrass extents, as well as better knowledge of bottlenose dolphin stock structures in the area, can close past data gaps and better address the conclusions presented here. Finally, this study presents important baseline information on the foraging behavior of bottlenose dolphins within Mississippi Sound that can be applied to future studies on the effects of the Deepwater Horizon oil spill. This event, contrary to Hurricane Katrina, likely caused long-term adverse effects within Mississippi Sound, and should galvanize future research examining the impacts of both natural and anthropogenic catastrophic events, as well as those cumulative factors discussed here and their role in impacts on marine mammal populations.

Acknowledgements. We thank the students, interns, and volunteers at the Marine Mammal Behavior and Cognition Laboratory at the University of Southern Mississippi and personnel of the Institute for Marine Mammal Studies for their assistance in data collection. A. Azzara, K. Goetz, B. Kar, and S. McBride, as well as 3 anonymous reviewers offered helpful comments and insight in developing this manuscript. Funding for this project was supported in part by the Dolphin Communication Fund at the University of Southern Mississippi and by grants from the Department of Commerce and the Institute for Marine Mammal Studies. All research efforts were conducted under permit \#1041-1701 through the National Marine Fisheries Service. 


\section{LITERATURE CITED}

Aguilar Soto NA, Johnson M, Madsen PT, Tyack PL, Bocconcelli A, Borsani JF (2006) Does intense ship noise disrupt foraging in deep-diving Cuvier's beaked whales (Ziphius cavirostris)? Mar Mamm Sci 22:690-699

- Allen MC, Read AJ, Gaudet J, Sayigh LS (2001) Fine-scale habitat selection of foraging bottlenose dolphins Tursiops truncatus near Clearwater, Florida. Mar Ecol Prog Ser 222:253-264

Allison MA, Sheremet A, Goni MA, Stone GW (2005) Storm layer deposition on the Mississippi-Atchafalaya subaqueous delta generated by Hurricane Lili in 2002. Cont Shelf Res 25:2213-2232

Altmann J (1974) Observational study of behavior: sampling methods. Behaviour 49:227-267

Ansmann IC, Parra GJ, Chilvers BL, Lanyon JM (2012) Dolphins restructure social system after reduction of commercial fisheries. Anim Behav 84:575-581

Anton A, Cebrian J, Duarte CM, Heck KL Jr, Goff J (2009) Low impact of Hurricane Katrina on seagrass community structure and functioning in the northern Gulf of Mexico. Bull Mar Sci 85:45-59

Ashe E, Noren DP, Williams R (2010) Animal behaviour and marine protected areas: incorporating behavioural data into the selection of marine protected areas for an endangered killer whale population. Anim Conserv 13:196-203

Balmer BC, Wells RS, Nowacek SM, Nowacek DP, Schwacke LH, McLellan WA, Scharf FS (2008) Seasonal abundance and distribution patterns of common bottlenose dolphins (Tursiops truncatus) near St. Joseph Bay, Florida, USA. J Cetacean Res Manag 10:157-167

Barros NB, Odell DK (1990) Food habits of bottlenose dolphins in the southeastern United States. In: Leatherwood $\mathrm{S}$, Reeves RR (eds) The bottlenose dolphin. Academic Press, San Diego, CA, p 309-328

Barros N, Wells R (1998) Prey and feeding patterns of resident bottlenose dolphins (Tursiops truncatus) in Sarasota Bay, Florida. J Mammal 79:1045-1059

Barros NB, Ostrom PH, Stricker CA, Wells RS (2010) Stable isotopes differentiate bottlenose dolphins off west-central Florida. Mar Mamm Sci 26:324-336

Bassos-Hull K, Wells R (2007) Investigating potential hurricane and red tide related impacts on bottlenose dolphin (Tursiops truncatus) abundance, reproductive rates, distribution, and site fidelity in Charlotte Harbor and Pine Island Sound, Florida. Mote Marine Laboratory Tech Rep \#1231, Sarasota, FL

Baumgartner MF (1997) The distribution of Risso's dolphin (Grampus griseus) with respect to the physiography of the northern Gulf of Mexico. Mar Mamm Sci 13:614-638

Benson NG (1982) Life history requirements of selected finfish and shellfish in Mississippi Sound and adjacent areas. FWS/OBS-81/51, US Fish \& Wildlife Service, Washington, DC

Berens McCabe EJ, Gannon DP, Barros NB, Wells RS (2010) Prey selection in a resident common bottlenose dolphin (Tursiops truncatus) community in Sarasota Bay, Florida. Mar Biol 157:931-942

Blake ES, Rappaport EN, Landsea CW (2007) The deadliest, costliest, and most intense United States tropical cyclones from 1851 to 2006 (and other frequently requested hurricane facts). NOAA Tech Mem NWS TPC-5

Blaylock RA, Hoggard W (1994) Preliminary estimates of bottlenose dolphin abundance in southern US Atlantic and Gulf of Mexico continental shelf waters. NOAA Tech Mem NMFS-SEFSC-356
Born EW, Outridge P, Riget FF, Hobson KA, Dietz R, Øien N, Haug T (2003) Population substructure of North Atlantic minke whales (Balaenoptera acutorostrata) inferred from regional variation of elemental and stable isotopic signatures in tissues. J Mar Syst 43:1-17

> Burkholder J, Eggleston D, Glasgow H, Brownie C and others (2004) Comparative impacts of two major hurricane seasons on the Neuse River and western Pamlico Sound ecosystems. Proc Natl Acad Sci USA 101:9291-9296

Carmichael RH, Graham WM, Aven A, Worthy G, Howden S (2012) Were multiple stressors a 'perfect storm' for Northern Gulf of Mexico bottlenose dolphins (Tursiops truncatus) in 2011? PLoS ONE 7:e41155

- Carter GA, Lucas KL, Biber PD, Criss GA, Blossom GA (2011) Historical changes in seagrass coverage on the Mississippi barrier islands, northern Gulf of Mexico, determined from vertical aerial imagery (1940-2007). Geocarto Int 26:663-673

Connell JH (1978) Diversity in tropical rain forests and coral reefs. Science 199:1302-1310

Davis RW, Fargion GS, May N, Leming TD and others (1998) Physical habitat of cetaceans along the continental slope in the north central and western Gulf of Mexico. Mar Mamm Sci 14:490-507

> Dreyer J, Bailey-Brock JH, McCarthy SA (2005) The immediate effects of Hurricane Iniki on intertidal fauna on the south shore of O'ahu. Mar Environ Res 59:367-380

Eide SD (1998) Correlations between bottlenose dolphin (Tursiops truncatus) distribution and presence of calves in Boca Ciega Bay, Florida and the Florida state ban on commercial netting. BSc thesis, Eckerd College, St. Petersburg, FL

Elliser CR, Herzing DL (2011) Replacement dolphins? Social restructuring of a resident pod of Atlantic bottlenose dolphins, Tursiops truncatus, after two major hurricanes. Mar Mamm Sci 27:39-59

ESRI ArcGIS Resource Center (2011a) Hot spot analysis (Getis-Ord $\mathrm{Gi}^{*}$ ) (spatial statistics). Available at: http: //help.arcgis.com/en/arcgisdesktop/10.0/help/index.html\#/ Hot_Spot_Analysis_Getis_Ord_Gi/005p00000010000000/ (accessed 6 June 2011)

ESRI ArcGIS Resource Center (2011b) Supplementary spatial statistics toolbox for ArcGIS 10. Available at: http: //resources.arcgis.com/gallery/file/geoprocessing/details? entryID=8E548CF9-1422-2418-8855-2ED418793771 (accessed 5 October 2011)

ESRI ArcGIS Resource Center (2011c) Generate spatial weights matrix (spatial statistics). Available at: http:// help.arcgis.com/en/arcgisdesktop/10.0/help/index.html\#// 005p00000020000000 (accessed 13 October 2011)

Fertl D (1994) Occurrence patterns and behavior of bottlenose dolphins (Tursiops truncatus) in the Galveston ship channel, Texas. Tex J Sci 46:299-318

Fritz HM, Blount C, Sokoloski R, Singleton J and others (2007) Hurricane Katrina storm surge distribution and field observations on the Mississippi barrier islands. Estuar Coast Shelf Sci 74:12-20

> Gannon DP, Waples DM (2004) Diets of coastal bottlenose dolphins from the US mid-Atlantic coast differ by habitat. Mar Mamm Sci 20:527-545

> Gannon DP, Barros NB, Nowacek DP, Read AJ, Waples DM, Wells RS (2005) Prey detection by bottlenose dolphins (Tursiops truncatus): an experimental test of the passive listening hypothesis. Anim Behav 69: 709-720

- Getis A, Ord JK (1992) The analysis of spatial association by use of distance statistics. Geogr Anal 24:189-206 
Gowans S, Whitehead H (1995) Distribution and habitat partitioning by small odontocetes in the Gully, a submarine canyon on the Scotian shelf. Can J Zool 73:1599-1608

Hanson MT, Defran RH (1993) The behaviour and feeding ecology of the Pacific coast bottlenose dolphin, Tursiops truncatus. Aquat Mamm 19:127-142

> Hastie GD, Wilson B, Wilson LJ, Parsons KM, Thompson PM (2004) Functional mechanisms underlying cetacean distribution patterns: hot spots for bottlenose dolphins are linked to foraging. Mar Biol 144:397-403

$>$ Heinsohn GE, Spain AV (1974) Effects of a tropical cyclone on littoral and sub-littoral biotic communities and on a population of dugongs (Dugong dugon (Müller)). Biol Conserv 6:143-152

> Hubard C, Maze-Foley K, Mullin K, Schroeder W (2004) Seasonal abundance and site fidelity of bottlenose dolphins (Tursiops truncatus) in Mississippi Sound. Aquat Mamm 30:299-310

Irvine AB, Scott MD, Wells RS, Kaufmann JH (1981) Movements and activities of the Atlantic bottlenose dolphin, Tursiops truncatus, near Sarasota, Florida. Fish Bull 79: 671-688

Kastelein RA, Vaughan N, Walton S, Wiepkema PR (2002) Food intake and body measurements of Atlantic bottlenose dolphins (Tursiops truncates) in captivity. Mar Environ Res 53:199-218

Langtimm CA, Krohn MD, Reid JP, Stith BM, Beck CA (2006) Possible effects of the 2004 and 2005 hurricanes on manatee survival rates and movement. Estuaries Coasts 29:1026-1032

Leatherwood S (1975) Some observations of feeding behavior of bottlenosed dolphins (Tursiops truncatus) in the northern Gulf of Mexico and (Tursiops cf. T. gilli) off southern California, Baja California, and Nayarit, Mexico. Mar Fish Rev 37:10-16

Love MR, Amante CJ, Eakins BW, Taylor LA (2012) Digital elevation models of the northern Gulf coast: procedures, data sources and analysis. NOAA Tech Mem NESDIS NGDC-59

> Lusseau D, Bain DE, Williams R, Smith JC (2009) Vessel traffic disrupts the foraging behavior of southern resident killer whales Orcinus orca. Endang Species Res 6:211-221

Mackey AD (2010) Site fidelity and association patterns of bottlenose dolphins (Tursiops truncatus) in the Mississippi Sound. MA thesis, University of Southern Mississippi, Hattiesburg, MS

Mann J (1999) Behavioral sampling methods for cetaceans: a review and critique. Mar Mamm Sci 15:102-122

- Marsh H (1989) Mass stranding of dugongs by a tropical cyclone in northern Australia. Mar Mamm Sci 5:78-84

Maze KS, Würsig B (1999) Bottlenose dolphins of San Luis Pass, Texas: occurrence patterns, site-fidelity, and habitat use. Aquat Mamm 25:91-104

Mignucci-Giannoni AA, Toyos-González GM, Pérez-Padilla J, Rodríguez-López MA, Overing J (1999) Mass stranding of pygmy killer whales (Feresa attenuata) in the British Virgin Islands. J Mar Biol Assoc UK 79:383-384

Miller LJ, Solangi M, Kuczaj SA (2008) Immediate response of Atlantic bottlenose dolphins to high-speed personal watercraft in the Mississippi Sound. J Mar Biol Assoc UK 88:1139-1143

Miller LJ, Mackey AD, Hoffland T, Solangi M, Kuczaj SA II (2010a) Potential effects of a major hurricane on Atlantic bottlenose dolphin (Tursiops truncatus) reproduction in the Mississippi Sound. Mar Mamm Sci 26:707-715

> Miller LJ, Solangi M, Kuczaj SA II (2010b) Seasonal and diurnal patterns of behavior exhibited by Atlantic bottle- nose dolphins (Tursiops truncatus) in the Mississippi Sound. Ethology 116:1127-1137

Miller LJ, Mackey AD, Solangi M, Kuczaj SA II (2012) Population abundance and habitat utilization of bottlenose dolphins in the Mississippi Sound. Aquat Conserv, doi: 10.1002/aqc. 2278

Mitchell A (2009) The ESRI guide to GIS analysis, Vol 2: spatial measurements and statistics. ESRI Press, Redlands, CA

Moncreiff CA (2007) Mississippi Sound and the Gulf Islands. In: Handley L, Altsman D, DeMay R (eds) Seagrass status and trends in the northern Gulf of Mexico: 1940-2002. USGS Scientific Investigations Report 2006-5287, p 76-85

Moncreiff CA, Randall TA, Caldwell JD (1998) Mapping of seagrass resources in Mississippi Sound: final report. Dept Mar Res, Gulf Coast Res Lab Project \#BY3-1563238, Biloxi, MS

> Morton RA (2008) Historical changes in the MississippiAlabama barrier-island chain and the roles of extreme storms, sea level, and human activities. J Coast Res 24: 1587-1600

Mullin KD (1988) Comparative seasonal abundance and ecology of bottlenose dolphins (Tursiops truncatus) in three habitats of the North-Central Gulf of Mexico. PhD dissertation, Mississippi State University, Starkville, MS

National Marine Fisheries Service (2007) Report to Congress on the impacts of Hurricanes Katrina, Rita, and Wilma on Alabama, Louisiana, Florida, Mississippi, and Texas Fisheries. NOAA, Silver Spring, MD

National Marine Fisheries Service (2012a) Monthly commercial landing statistics. Available at: www.st.nmfs.noaa. gov/commercial-fisheries/commercial-landings/monthlylandings/index (accessed 29 December 2012)

National Marine Fisheries Service (2012b) Total commercial fishery landings at an individual US port for all years after 1980. Available at www.st.nmfs.noaa.gov/st1/commercial/ landings/lport_hist.html (accessed 14 April 2012)

NOAA Fisheries (2013) 2010-2013 cetacean unusual mortality event in northern Gulf of Mexico. Available at www.nmfs. noaa.gov/pr/health/mmume/cetacean_gulfofmexico2010. htm (accessed 27 June 2013)

> Nowacek DP (2005) Acoustic ecology of foraging bottlenose dolphins (Tursiops truncatus), habitat-specific use of three sound types. Mar Mamm Sci 21:587-602

> Peneva E, Griffith JA, Carter GA (2008) Seagrass mapping in the northern Gulf of Mexico using airborne hyperspectral imagery: a comparison of classification methods. J Coast Res 24:850-856

Preen AR, Marsh H (1995) Response of dugongs to largescale loss of seagrass from Hervey Bay, Queensland, Australia. Wildl Res 22:507-519

Quinn GP, Keough MJ (2002) Experimental design and data analysis for biologists. Cambridge University Press, Cambridge

Reddy M, Kamolnik T, Skaar D, Curry C, Ridgway S (1991) Bottlenose dolphins: energy consumption during pregnancy, lactation, and growth. Proc 1991 Int Mar Anim Trainers Assoc Conf, Vallejo, CA, p 30-37

> Redfern JV, Ferguson MC, Becker EA, Hyrenbach KD and others (2006) Techniques for cetacean-habitat modeling. Mar Ecol Prog Ser 310:271-295

Rosel PE, Watts H (2008) Hurricane impacts on bottlenose dolphins in the northern Gulf of Mexico. Gulf Mex Sci 1: 88-94

Rossman S, Barros NB, Stricker CA, Gandhi H, Ostrom PH, Wells RS (2011) Foraging ecology of bottlenose dolphins: a stable isotopic reconstruction over six decades docu- 
ments anthropogenic disturbance. 19th Bienn Conf Biol Mar Mamm. Society for Marine Mammalogy, Tampa, FL, p 258 (Abstract)

Scott MD, Wells RS, Irvine AB (1996) Long-term studies of bottlenose dolphins in Florida. IBI Rep 6:73-81

Shane SH (1990) Behavior and ecology of the bottlenose dolphin at Sanibel Island, Florida. In: Leatherwood S, Reeves RR (eds) The bottlenose dolphin. Academic Press, San Diego, CA, p 245-265

Stevens PW, Blewett DA, Casey JP (2006) Short-term effects of a low dissolved oxygen event on estuarine fish assemblages following the passage of Hurricane Charley. Estuaries Coasts 29:997-1003

Tomasko DA, Anastasiou C, Kovach C (2006) Dissolved oxygen dynamics in Charlotte Harbor and its contributing watershed, in response to hurricanes Charley, Frances, and Jeanne-impacts and recovery. Estuaries Coasts 29: 932-938

Wade PR, Angliss RP (1997) Guidelines for assessing marine mammal stocks: Report of the GAMMS workshop, April 3-5, 1996, Seattle, WA. NOAA Tech Mem NMFS-OPR-12

Walker JL, Potter CW, Macko SA (1999) The diets of modern and historic bottlenose dolphin populations reflected through stable isotopes. Mar Mamm Sci 15:335-350

Waples DM (1995) Activity budgets of free-ranging bottlenose dolphins (Tursiops truncatus) in Sarasota Bay,
Florida. MSc thesis, University of California, Santa Cruz, CA

Wells RS, Scott MD, Irvine BA (1987) The social structure of free-ranging bottlenose dolphins. In: Genoways H (ed) Current mammalogy, Vol 1. Plenum Press, New York, NY, p 247-305

Whitehead A, Dubansky B, Bodinier C, Garcia TI and others (2011) Genomic and physiological footprint of the Deepwater Horizon oil spill on resident marsh fishes. Proc Natl Acad Sci USA 108:6193-6198

Wilson CJ, Wilson PS, Greene CA, Dunton KH (2013) Seagrass meadows provide an acoustic refuge for estuarine fish. Mar Ecol Prog Ser 472:117-127

Witteveen BH, Worthy GAJ, Wynne KM, Roth JD (2009) Population structure of North Pacific humpback whales on their feeding grounds revealed by stable carbon and nitrogen isotope ratios. Mar Ecol Prog Ser 379:299-310

Worthy GAJ, Worthy TAM, Browning N (2011) Seasonal variability in the trophic ecology of bottlenose dolphins and their potential prey in the Indian River Lagoon, FL. Final Report to Harbor Branch Oceanographic Institute for Project Number HBOI PO 0012407

Würsig B (1986) Delphinid foraging strategies. In: Schusterman R, Thomas J, Wood FG (eds) Dolphin cognition and behavior: a comparative approach. Lawrence Erlbaum Associates, Hillsdale, NJ, p 347-359

Appendix 1. Sightings $\mathrm{km}^{-1}$ effort analyzed: temporal splits used in spatial analysis

\begin{tabular}{|llc|}
\hline Temporal split & Example & $\begin{array}{c}\text { Number of files } \\
\text { analyzed }\end{array}$ \\
\hline All data & All data files (no splits) & 1 \\
Overall by year & 2003 (all data), 2004 (all data), etc. & 7 \\
Overall by month & January all years, February all years, etc. & 12 \\
Overall by season & Summer (all years), winter (all years) & 2 \\
Overall by season year & Summer 2003, summer 2004, etc. & 14 \\
Overall pre-Kat & All data pre-Katrina & 1 \\
Overall post-Kat & All data post-Katrina & 1 \\
Pre-Kat by month & 'January' for all years before Katrina & 12 \\
Post-Kat by month & 'January' for all years post-Katrina & 12 \\
Pre-Kat by season & Winter for all files before Katrina & 2 \\
Post-Kat by season & Winter for all files post-Katrina & 2 \\
\hline
\end{tabular}

Appendix 2. Survey effort (km) for each of the islands, calculated within the $1 \mathrm{~km}$ buffer zone (see Fig. 1). Note: tracks also occurred outside of the buffer zone

\begin{tabular}{|lcccc|}
\hline Island & Pre-Kat & Post-Kat 1 & Post-Kat 2 & Total \\
\hline Cat & 1515.92 & 784.66 & 637.13 & 2937.71 \\
Ship & 1174.56 & 882.04 & 782.31 & 2838.91 \\
Horn & 122.56 & 545.27 & 716.02 & 1383.85 \\
Deer & 14.44 & 12.60 & 27.31 & 54.35 \\
Petit Bois & 35.96 & 0 & 0 & 35.96 \\
Total & 2863.44 & 2224.57 & 2162.77 & \\
\hline
\end{tabular}

